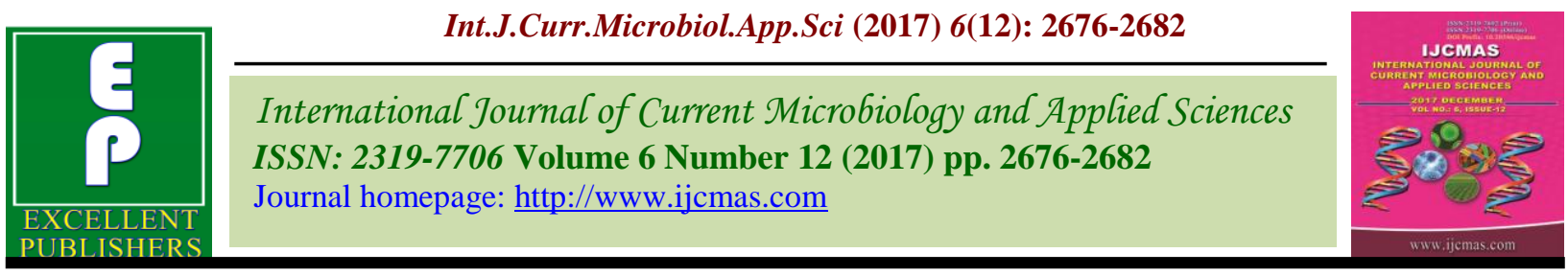

Original Research Article

https://doi.org/10.20546/ijcmas.2017.612.309

\title{
Assessment of Diverse Substrates for Quality Wines Production
}

\author{
Sourav Kumar*, Pooja Nikhanj and Gurvinder Singh Kocher \\ Department of Microbiology, Punjab Agricultural University, Ludhiana-141004, Punjab, India \\ *Corresponding author
}

\section{A B S T R A C T}

\begin{tabular}{|l|}
\hline K e y w o r d s \\
Antioxidants, Black \\
carrots, Chikoo, \\
Mixed fruit juice, \\
Rose, Wine.
\end{tabular}

\section{Introduction}

The talent to produce appetizing effervescent beverage and wine by alcoholic fermentation of natural fruit juices is a revelation of inherent ingenuity of man. Fruit wines are fermented alcoholic beverages made from a variety of base ingredients (other than grapes) such as fruits, vegetables, flowers, and herbs; that add additional flavors. Most fruits and berries have the potential to produce wine. Few fruits other than grapes have the balanced quantities of sugar, acid, tannin, nutritive salts for yeast feeding and water to naturally produce a stable, drinkable wine, so most country wines are adjusted in one or more respects for fermentation of local fruits to produce their wines (Okunowo et al., 2005).

There are plenty of tropical fruits and vegetables in India which includes guava, watermelon, pineapple, plum, papaya, orange, black carrots, muskmelon, watermelon etc that are rich in nutrients. These fruits are highly perishable, and prone to bacterial and fungal contamination as a result they fail to reach the market due to spoilage, mechanical damage and over ripeness (Ihekoroye and Ngoddy, 1985). Besides, these fruits are difficult to keep for considerable length of time; hence the ripe fruits are utilized either 
as fresh or processed into juice and specialty products (Oyeleke and Olaniyan, 2007). High rate wastage of these fruits and vegetables especially at their peak of production season necessitates the need for alternative preservation and post-harvest technologies towards an enhanced utilization of these fruits.

Fruit juices are fermented to produce wine, an undistilled nutritional alcoholic beverage. Using species of Saccharomyces cerevisiae which converts the sugar in the fruit juices into alcohol and organic acids, that later react to form aldehydes, esters and other chemical compounds which also help to preserve the wine (Fleet 2003; Duarte et al., 2010; Isitua and Ibeh, 2010). Home-made wine production has been practiced with various fruits such as apple, pear and strawberry, cherries, oranges, watermelon, guava, etc. Yeasts from other sources such as palm wine has also been used (Ayogu, 1999) in the production of fruit wine. Evaluating different fruits, vegetables and herbs for wine production is always being a new area of research in terms of wine diversification. The production of wines from common fruits and vegetables can also help reduce the level of post-harvest losses besides increasing diversity of wines in India (Okoro 2007; Alobo and Offonry, 2009).

The present study evaluated the fruit (Chikoo), vegetable (black carrot), herb (rose) and mixed fruit juice waste for production of quality wines.

\section{Materials and Methods}

\section{Procurement of culture}

Pure culture of Saccharomyces cerevisiae MTCC 11815 was collected from Department of Microbiology, PAU, Ludhiana, India and sub-cultured on Glucose yeast extract (GYE) agar medium and stored in refrigerator at $4^{\circ} \mathrm{C}$.

\section{Inoculum preparation}

The inoculum was prepared by inoculating the slant culture in $100 \mathrm{ml}$ of sterile GYE broth taken in $250 \mathrm{ml}$ capacity flask and cultured on a rotary shaker (100rpm) for 24 hours.

\section{Seed culture preparation}

From the prepared inoculum of Saccahromyces cerevisiae 11815, 5\% (v/v) was added to the required amount of respective juices $(5 \% \mathrm{v} / \mathrm{v})$ and kept on a rotary shaker (100rpm) for 24 hours at $28 \pm 2^{\circ} \mathrm{C}$ for incubation for seed culture preparation.

\section{Extraction of juice}

Black carrots (10 kg), Chikoo (2kg), mixed fruit juice $(2.5 \mathrm{~kg})$ and grapes $(10 \mathrm{~kg})$ were taken, washed, peeled (except for fruit juice) and juice was extracted that yielded 5L of black carrots and grape juice and 1L of each Chikoo and mixed fruit juice from respective substrates. Physiocochemical analysis of juices were carried out to estimate TSS, pH, acidity, total sugars (Dubois et al., 1956), reducing sugars (Miller, 1959), ascorbic acid (AOVC, 1996), anthocyanins (Zoecklein, 2005), total phenols (Malik and Singh, 1991). Sugar was chaptalized to adjust final Total Soluble Solids (TSS) of all juices to $20-22^{\circ}$ Brix for ethanolic fermentation.

Potassium metabisulphite (KMS) was added @ 100mg/L to all juices to avoid growth of wild yeast. Following pasteurization of juices at $60^{\circ} \mathrm{C}-65^{\circ} \mathrm{C}$ for 10 minutes, cooled juices were inoculated with their respective seed cultures of wine yeast Saccharomyces cerevisiae 11815 @ 5\% (v/v) and Diammonium hydrogen orthophosphate (DAHP) was supplemented @ 0.2\% (w/v) as a source of nitrogen and phosphorus for yeast 
growth. Fermentations were carried out under controlled temperature conditions of $28 \pm 2^{\circ} \mathrm{C}$ till ${ }^{\circ}$ Brix falls to zero. Periodic samples of different ongoing fermentations were taken and analysed for ${ }^{\circ} \mathrm{Brix}$ (By hydrometer), $\mathrm{pH}$ (pH meter; Hanna HI96107), acidity (Amerine and Roessler, 1976) and ethanol content (Caputi et al., 1968).

\section{Total antioxidant activity}

DPPH (2,2-diphenyl-1-picrylhydrazyl) method was used to determine free radical scavenging activity of wines according to the method of Sanchez-Moreno et al., (1999). $\mathrm{EC}_{50}$ value is the effective concentration of the sample showing 50\% inhibition of free radical generation (Shimamura et al., 2014).

The percent inhibition was calculated as following:

O.D (Control) - O.D (Test sample)

Percent inhibition $=-------------------\times 100$

O.D (Control)

Ascorbic acid equivalent antioxidant activity (AEAC) was calculated as:

$\mathrm{AEAC}=\frac{\mathrm{EC}_{50} \text { of ascorbic acid }(\mu \mathrm{M})}{\mathrm{EC}_{50} \text { of sample }(\mu \mathrm{M})}$

The higher AEAC value means the higher free radical scavenging activity.

\section{Results and Discussion}

Physicochemical analysis and ethanolic fermentation of various juices

\section{Black carrots wine}

Black carrots juice showed the initial TSS content of $4.7^{\circ} \mathrm{B}$ with $3.6 \%$ total sugars and $3.2 \%$ reducing sugars (Table 1 ). Juice was chaptalized to raise the sugar level to $22^{\circ} \mathrm{B}$ before inoculation with $S$. cerevisiae seed culture. During the fermentation period of 5 days, $\mathrm{pH}$ drops to 4.4 from 5.5 , acidity drops to $0.25 \%$ with non-significant decrease in ascorbic acid and anthocyanins content. While total phenolics content increased from 96.8 to $106.8(\mathrm{mg} / 100 \mathrm{ml})$ due to production of various secondary metabolites by yeast.

Final wine had $13.1 \%$ (v/v) ethanol content with fermentation efficiency of $93.0 \%$ (Table 2). In a similar study, Kocher et al., (2016) reported the fermentation of black carrots juice using S. cerevisiae 5\% (v/v) of starter inoculum culture and incubation at $25^{\circ} \mathrm{C}$ that lead to an ethanol content of $10.8 \%(\mathrm{v} / \mathrm{v})$ with fermentation efficiency of $94.7 \%$ and an ethanol yield of $0.48 \mathrm{~g} / \mathrm{g}$ of sugar.

\section{Chikoo wine}

Chikoo juice fermentation took 3 days to descend the fermentable sugars to $0^{\circ} \mathrm{B}$ from $20^{\circ} \mathrm{B}$ chaptalized by sugar from initial $8.9^{\circ} \mathrm{B}$ (Table 1 and 2). During the fermentation $\mathrm{pH}$ decreased from 5.4 to 4.6 , acidity decreased to $0.24 \%$ and final ethanol content was $9.7 \%$ $(\mathrm{v} / \mathrm{v})$ produced with fermentation efficiency of $75.7 \%$.

\section{Mixed fruit wine}

Mixed Fruit juice had $4.3^{\circ} \mathrm{B}$ that was increased to $22^{\circ} \mathrm{B}$. Fermentation of mixed fruit juice yielded $13.4 \%(\mathrm{v} / \mathrm{v})$ ethanol in 4 days with the fermentation efficiency of $95.1 \%$. $\mathrm{pH}$ decreased to 4.6 from 5.8 , acidity decreased to $0.25 \%$ during the process (Table 1). Gavimath et al., (2012) also evaluated the different fruits (papaya, banana, orange and lime fruits) Comparative analysis of wine prepared from them revealed that banana fruits yield good quantity and quality alcohol $(15.49 \%)$ when compare papaya orange and lime. 
Table.1 Physicochemical analysis of black carrot, chikoo, mixed fruit juice and grape rose juice

\begin{tabular}{|l|c|c|c|c|}
\hline Parameter & $\begin{array}{c}\text { Black } \\
\text { carrot }\end{array}$ & Chikoo & $\begin{array}{c}\text { Mixed fruit } \\
\text { juice }\end{array}$ & $\begin{array}{c}\text { Grape Rose } \\
\text { wine }\end{array}$ \\
\hline TSS & 4.7 & 8.9 & 4.3 & 16.8 \\
\hline Total sugars & 3.6 & 8.3 & 4.0 & 16.3 \\
\hline Reducing sugars & 3.2 & 7.9 & 3.2 & 15.6 \\
\hline pH & 5.5 & 5.4 & 5.8 & 4.3 \\
\hline Acidity $(\% \mathrm{w} / \mathrm{v})$ & 0.46 & 0.38 & 0.41 & 0.59 \\
\hline Total phenols $(\mathrm{mg} / 100 \mathrm{ml})$ & 96.8 & 76.8 & 70.1 & 232.6 \\
\hline Ascorbic acid(mg/100ml) & 3.62 & 26.3 & 86.9 & 587.1 \\
\hline Anthocyanins $(\mathrm{mg} / 100 \mathrm{ml})$ & 179.1 & 1.88 & 4.80 & 38.5 \\
\hline
\end{tabular}

Table.2 Ethanolic fermentation of Black carrots, chikoo, mixed fruit juice and grape rose juice and comparative wine profile

\begin{tabular}{|c|c|c|c|c|}
\hline Wine & Black carrot & Chikoo & $\begin{array}{c}\text { Mixed fruit } \\
\text { juice }\end{array}$ & Grape rose wine \\
\hline $\begin{array}{l}\text { Fermentation scale } \\
(\mathrm{L})\end{array}$ & $5 \mathrm{~L}$ & $1 \mathrm{~L}$ & $1.5 \mathrm{~L}$ & $5 \mathrm{~L}$ \\
\hline Initial TSS $\left({ }^{\circ} \mathrm{B}\right)$ & $22^{\circ} \mathrm{B}$ & $20^{\circ} \mathrm{B}$ & $22^{\circ} \mathrm{B}$ & $21^{\circ} \mathrm{B}$ \\
\hline Final TSS $\left({ }^{\circ} \mathrm{B}\right)$ & $0^{\circ} \mathrm{B}$ & $0^{\circ} \mathrm{B}$ & $0^{\circ} \mathrm{B}$ & $0^{\circ} \mathrm{B}$ \\
\hline $\mathrm{pH}$ & 4.4 & 4.6 & 4.6 & 4.5 \\
\hline Acidity (\%w/v) & 0.25 & 0.24 & 0.25 & 0.26 \\
\hline Alcohol (\%v/v) & 13.1 & 9.7 & 13.4 & 12.3 \\
\hline $\begin{array}{c}\text { Days to complete } \\
\text { fermentation }\end{array}$ & 5 & 3 & 4 & 7 \\
\hline $\begin{array}{c}\text { Fermentation } \\
\text { efficiency }(\%)\end{array}$ & $93.0 \%$ & $75.7 \%$ & $95.1 \%$ & $91.5 \%$ \\
\hline $\begin{array}{c}\text { Total phenols } \\
(\mathrm{mg} / 100 \mathrm{ml})\end{array}$ & 106.8 & 85.9 & 74.8 & 276.7 \\
\hline $\begin{array}{c}\text { Ascorbic acid } \\
(\mathrm{mg} / 100 \mathrm{ml})\end{array}$ & 3.06 & 24.9 & 84.8 & 564.2 \\
\hline $\begin{array}{l}\text { Anthocyanins } \\
(\mathrm{mg} / 100 \mathrm{ml})\end{array}$ & 178.1 & 1.37 & 4.82 & 37.9 \\
\hline
\end{tabular}

Table.3 DPPH scavenging activity in respect of concentrations of black carrot, chikoo, mixed fruit and grape rose wine

\begin{tabular}{|c|c|c|c|}
\hline Wine & \% DPPH inhibition & EC $_{\mathbf{5 0}}$ Value & AEAC $(\boldsymbol{\mu M})$ \\
\hline Black carrot & 76.0 & 63.4 & 0.27 \\
\hline Chikoo & 30.0 & 179.7 & 0.09 \\
\hline Mixed fruit & 50.1 & 100.0 & 0.17 \\
\hline Grape rose & 88.9 & 53.01 & 0.32 \\
\hline
\end{tabular}


Fig.1 Percent DPPH scavenging activity of rose, black carrot, mixed fruit and chikoo wine with ascorbic acid as positive control for calculating $\mathrm{EC}_{50}$ values $(\mathrm{y}=\mathrm{Ax}+\mathrm{B})$

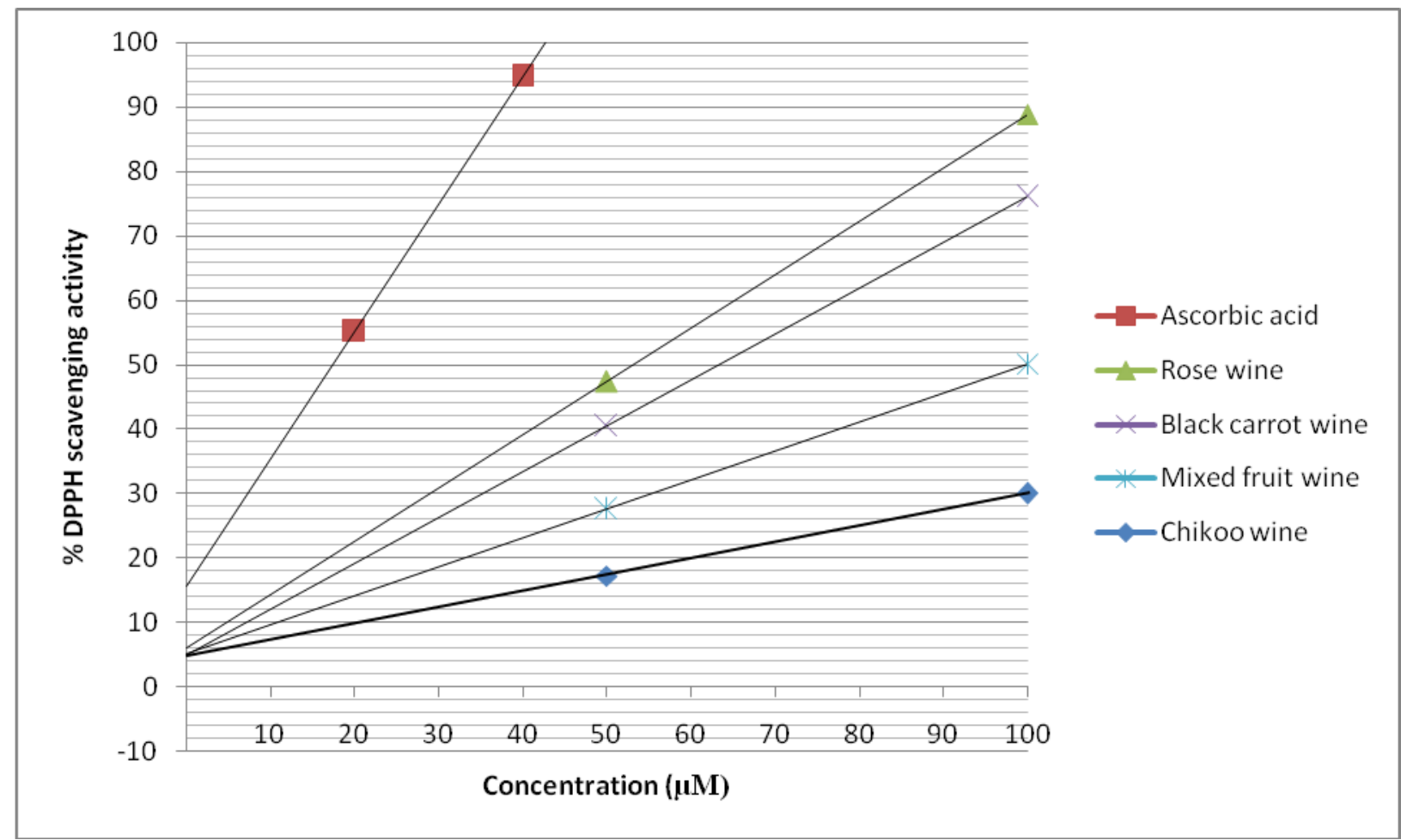

\section{Grape rose wine}

Grape juice $\left(16.8^{\circ} \mathrm{B}\right)$ was supplemented with rose petals and physicochemically analysed. Rose petals known to increase the phenolics, flavonoids and anthocyanin content in the grape juice that add a characteristic dry flavor to the resulting wine. Phenolic content (232.6 $\mathrm{mg} / 100 \mathrm{ml})$, ascorbic acid $(587.1 \mathrm{mg} / 100 \mathrm{ml})$ and anthocyanins $(38.5 \mathrm{mg} / 100 \mathrm{ml})$ was found in ample amount in the juice after addition of rose petals. Grape rose juice $\left(22^{\circ} \mathrm{B}\right)$ fermentation completed in 7 days with production of wine with ethanol content $12.3 \%(\mathrm{v} / \mathrm{v})$ with fermentation efficiency of $91.5 \%$ (Table 1 and 2). With a non-significant decrease in anthocyanins and ascorbic acid, phenolics showed a significant increase during the fermentation process. Earlier, Kumar et al., (2017) reported the ethanolic fermentation of grape and guava juice at 50L scale by inoculating freshly prepared $24 \mathrm{~h}$ old inoculum of $S$. cerevisiae MTCC 11815 (in jaggary solution@ $150 \mathrm{~g} / \mathrm{l}) @ 6 \%(\mathrm{v} / \mathrm{v})$ and $9 \%(\mathrm{v} / \mathrm{v})$, respectively followed by incubation at $28 \pm 2{ }^{\circ} \mathrm{C}$ (Pooja et al., 2014).

\section{Total antioxidant activity of wines}

Antioxidant activity was in terms of \% inhibition of DPPH was determined for wines produced. DPPH scavenging activity (Table 3) for black carrot, Chikoo, mixed fruit juice and grape rose wines were tested for determination of $\mathrm{EC}_{50}$ values (Fig. 1) and AEAC values. Results revealed that concentrations of rose, black carrot, mixed fruit and Chikoo wine needed for $50 \%$ inhibition were 53.01, 63.4, 100.0 and 179.7 $\mu \mathrm{M}$ and their AEAC values were 0.32, 0.27, 0.17 and $0.09 \mu \mathrm{M}$, respectively. Further, the concentration of ascorbic acid taken as positive control needed for $50 \%$ inhibition was $17.2 \mu \mathrm{M}$. Earlier, grape juice has been 
shown to possess DPPH activity in the range of $8.23 \pm 0.17,2.51 \pm 0.03$ and $8.24 \pm 0.19$ $\mathrm{mM}$ in homemade, commercial and organic juice respectively (Burin et al., 2010). Fruit wines reported to contain significantly higher total polyphenol content and hence possess greater antioxidant capacity compared to distilled beverages (Pinsirodom et al., 2010).

Wines produced from different fruits i.e. rose, black carrot, mixed fruit and Chikoo having 12.3, 13.1, 13.4 and $9.7(\% \mathrm{v} / \mathrm{v})$ ethanol, respectively. Grape rose wine and black carrot wine reported to have high ability to scavenge free radicals (88.9 and $76.0 \%$, respectively) due to excess anthocyanins content. Whereas mixed fruit wine and Chikoo wine have low but significant 50.1 and $30.0 \%$ free radical scavenging activity. Hence, all evaluated substrates (black carrots, Chikoo, mixed fruit juice and grape juice with rose petals) wines can act as a nutritional source for people providing an ample amount of antioxidants and other nutrients.

\section{References}

Alobo, A. P., and Offonry, S. U. 2009. Characteristics of coloured wine produced from Roselle (Hibiscus sabdariffa) calyx extract. J Inst Brew. 115, 91-94.

Amerine, M. A., H. W. Berg, and Guess, W. C. 1967. Evaluation of Wines and Brandies. In: The technology of wine making. $2^{\text {nd }}$ edn. The AVI Publishing Co. Inc. Westport, USA, 678-60.

AOVC. 1996. Methods of Vitamin Assay. In : Association of Vitamin Chemists Inc. $1^{\text {st }}$ ed. Interscience Publishers, New York, 79-81.

Ayogu, T. E. 1999. Evaluation of the performance of yeast isolate from Nigeria palm wine in wine production from pineapple fruits. Bioresour Technol. 69, 189-190.
Burin, V. M., L. D. Falcao, L. V. Gonzaga, R. Fett, J. P. Rosier, and Bordignon-Luiz1, M. T. 2010. Colour, phenolic content and antioxidant activity of grape juice. Cienc Technol Aliment Campinas. 30(4): 1027-1032.

Caputi, A. Jr., and Wright, D. 1969. Collaborative study of determination of ethanol in wine by chemical oxidation. $\mathbf{J}$ Assoc Anal Chem. 52, 85.

Duarte, W. F., D. R. Dias, M. J. Oliveira, J. A. Teixeira, J. D. Silva, and Schwan, R. F. 2010. Characterization of different fruit wines made from cocoa, cupuassu, gabiroba, jaboticaba and umbu. Food Sci Technol. 30, 1-9.

Dubois, M., Giles, K. A., Hamilton, J. K., Rebers, P. A., and Smith, F. 1956. Colorimetric method for determination of sugars and related substances. Anal Chem. 28, 350-56.

Fleet, G. H. 2003. Yeast interaction and wine flavour. Int J Food Microbiol. 86, 1122.

Gavimath, C. C., D.P. Kalsekar, C.J. Raorane, S. M. Kulkarni, B. G. Gavade, B.E. Ravishankar, and Hooli, V. R. 2012. Comparative analysis of wine from different fruits. Int $\mathrm{J}$ Advanced Biotechnol Res. 3 (4): 810 -813.

Ihekoroye, A. I., and Ngoddy, P.O. 1985. Integrated Food Science and Technology for the Tropics Macmillan Publisher, London.

Isitua, C. C., and Ibeh, I. N. 2010. Novel method of wine production from banana (Musa acuminata) and pineapple (Ananas cosmosus) waste. Afr J Biotechnol. 9(44): 7521-7524.

Kocher, G. S., Pooja, A. Brar, and Dhillon, T. S. 2016. Fermentative production of alcoholic beverage from black carrot. Agric Res J. 53 (1): 138-140.

Kumar, S., Kocher, G. S., and Bakshi, D. K. 2017. Fermentative Production of Vinegar from Grapes and Guava Using 
Adsorbed Cells of Acetobacter aceti. Int.J.Curr.Microbiol.App.Sci. 6(5), 2005-2012.

Malik, C. B., and Singh, M. B. 1991. Plant enzymology and Histoenzymology. $1^{\text {st }}$ edn. Kalyani publishers, New Delhi, 231-33.

Miller, G. L. 1959. Use of dinitrosalicylic acid reagent for determination of reducing sugar. Anal Chem. 31, 426-28.

Okoro, C. E. 2007. Production of red wine from roselle (Hibiscuss abdariffa) and pawpaw (Carica papaya) using palmwine yeast (Saccharomyces cerevisiae). Niger Food J. 25, 158-164.

Okunowo, W. O., R. O. Okotore, and Osuntoki, A. A. 2005. The alcoholic fermentative efficiency of indigenous yeast strains of different origin on orange juice. Afr J Biotechnol. 4, 12901296.

Oyeleke, F. I., and Olaniyan, A. M. 2007. Extraction of juice from some tropical fruits using a small scale multi-fruit juice extractor. Afr. Crop Sci. Proc. 8, 1803-1808.

Pinsirodom, P., J. Rungcharoen, and
Liumminful, A. 2010. Quality of commercial wine vinegars evaluated on the basis of total polyphenol content and antioxidant properties. As J Food AgInd. 3(4): 389-397.

Pooja, and Kocher, G. S. 2014. Fermentative production of guava-wine (Psidium guajava $\mathrm{L}$ ) using $S$. cerevisiae MTCC 11815. Curr. Nutri. Food Sci.10, 1.

Sanchez-Moreno, C., J. A. Larrauri, and Saura-Calixto, F. 1999. Free radicals scavenging capacity and inhibition of lipid oxidation of wines, grape juices and related polyphenolic constitutes. Fd Res Int. 32, 407-12.

Shimamura, T., Y. Sumikura, T. Yamazaki, A. Tada, T. Kashiwagi, H. Ishikawa, T. Matsui, N. Sugimoto, H. Akiyama, and Ukeda, H. 2014. Applicability of the DPPH assay for evaluating the antioxidant capacity of food additives inter - laboratory evaluation study. Anal Sci. 30, 717-721.

Zoecklein, B. 2005. Wine analysis and production. $5^{\text {th }}$ edn. Chapman \& Hall, New York, 45-46.

\section{How to cite this article:}

Sourav Kumar, Pooja Nikhanj and Gurvinder Singh Kocher. 2017. Assessment of Diverse Substrates for Quality Wines Production. Int.J.Curr.Microbiol.App.Sci. 6(12): 2676-2682. doi: https://doi.org/10.20546/ijcmas.2017.612.309 